\title{
Implementasi Pemberian Informasi Publik Pada Badan Pemeriksa Keuangan Perwakilan Provinsi Jambi Berdasarkan Undang-Undang Nomor 14 Tahun 2008 Tentang Keterbukaan Informasi Publik
}

\author{
Herma Yanti ${ }^{1}$ \\ Fakultas Hukum Universitas Batanghari \\ Jalan Slamet Riyadi Broni Kota Jambi Telp: (0741) 65351 \\ Correspondence email: hermayanti67@gmail.com
}

\begin{abstract}
Abstrak. Penelitian ini bertujuan untuk mengetahui implementasi pemberian informasi publik pada BPK Perwakilan Provinsi Jambi berdasarkan UU Nomor 14 Tahun 2008 tentang Keterbukaan Informasi Publik serta masalah-masalah yang dihadapi dan upaya yang dilakukan untuk mengatasi permasalahan tersebut. Karena itu penelitian ini merupakan penelitian hukum empiris dengan pendekatan socio legal research. Data-data penelitian dikumpulkan melalui studi dokumen dan wawancara dengan responden dan informan yang relevan dengan objek penelitian. Dari hasil penelitian diketahui bahwa implementasi pemberian informasi public pada BPK Perwakilan Provinsi Jambi telah mencerminkan asas-asas pemberian layanan informasi public sebagaimana diatur dalam UU KIP. Informasi Publik disediakan secara terbuka melalui saluran Penyediaan dan pemberian informasi publik dilakukan secara langsung melalui Pusat Informasi dan Komunikasi (PIK) dan juga dapat diakses melalui website BPK, sehingga memungkinkan masyarakat memperoleh berbagai informasi publik yang dikelola BPK dengan cepat dan mudah tanpa dipungut biaya. Meskipun demikian, dalam pemberian informasi tersebut ditemui permasalahan-permasalahan, disebabkan oleh tingginya tingkat keingintahuan masyarakat terhadap BPK Perwakilan Provinsi Jambi belum diimbangi dengan tingkat pemahaman masyarakat terhadap tugas an fungsi BPK beserta kebijakan dan prosedur pemberian informasi public oleh BPK. Karena itu perlu diimbangi dengan peningkatan sosialisasi kepada masyarakat sehingga terwujud lingkungan keterbukaan informasi publik yang lebih menjamin pemenuhan kebutuhan masyarakat dalam memperoleh informasi.
\end{abstract}

Kata kunci: Implementasi, keterbukaan informasi publik, BPK Perwakilan Provinsi Jambi.

\begin{abstract}
This research aims to determine the implementation of public information on BPK Jambi Provincial representative under UU No. 14 of 2008 on public information disclosure and the problems faced and efforts to resolve the issue. Therefore, this research is an empirical research law with a socio approach to legal research. Research data is collected through document studies and interviews with respondents and informant that are relevant to the research object. From the results of the research is known that the implementation of public information in BPK Jambi Provincial representatives has reflected the principles of providing public information services as stipulated in the UU KIP. Public information is provided openly through the provision and provision of public information conducted directly through the Information and Communication Center (PIK) and also accessible through the BPK website, so as to enable the public to obtain a variety of public information that is managed by the $B P K$ quickly and easily free of charge. Nevertheless, in the provision of information encountered problems, caused by the high level of public curiosity to the BPK provincial representatives have not been balanced with the level of public understanding of the task of the BPK function along with the policies and procedures of providing public information by BPK. Because it needs to be balanced with the improvement of socialization to the community so that the environment is manifested public information disclosure that more guarantees the fulfillment of community needs in obtaining information.
\end{abstract}

Keywords: implementation, disclosure of public information, BPK Provincial representative Jambi.

\section{PENDAHULUAN}

Keterbukaan informasi publik merupakan salah satu aspek penting dalam mewujudkan penyelenggaraan negara yang baik. Selain berfungsi sebagai sarana dalam mengoptimalkan pengawasan publik terhadap penyelenggaraan negara dan badan publik lainnya, keterbukaan informasi publik diperlukan sebagai upaya dalam pemenuhan hak asasi manusia untuk memperoleh informasi sebagaimana tercermin dalam Pasal 28F Undang-Undang Dasar Negara Republik Indonesia Tahun 1945.

Program keterbukaan informasi di era informasi teknologi sekarang ini sangat strategis dan relevan dengan kebutuhan masyarakat modern yang demokratis, yang menjunjung tinggi nilai-nilai kebenaran, keadilan, transparansi, akuntabilitas dan kesetaraan di depan hukum. ${ }^{2}$ Adanya keterbukaan informasi publik juga dapat mendorong suatu

${ }^{1}$ Herma Yanti, Dosen PS Ilmu Hukum Fakultas Hukum Universitas Batanghari Jambi

${ }^{2}$ Zahari, Implementasi Keterbukaan Informasi Melalui Optimalisasi Meja Informasi di Pengadilan Agama, diakses dari http://www.academia.edu/9253471. Diakses Tangal 31Desember 2019 
masyarakat menjadi lebih demokratis dengan memungkinkan adanya akses masyarakat terhadap informasi yang dimiliki pemerintah maupun lembaga-lembaga publik lainnya. ${ }^{3}$

Guna menjamin terpenuhinya hak masyarakat untuk mendapatkan informasi sera terwujudnya penyelenggaraan negara yang transparan, akuntanbel, dan dapat dipertanggungjawabkan sekaligus sebagai pedoman bagi badan publik untuk menghasilkan layanan informasi yang berkualitas dan menjangkau seluruh masyarakat, Pemerintah telah menetapkan Undang-Undang Nomor 14 Tahun 2008 tentang Keterbukaan Informasi Publik (UU KIP). Dalam Pasal 7 ayat (1) mengamanahkan secara tegas tentang kewajiban bagi setiap badan publik untuk menyediakan, memberikan atau menerbitkan informasi publik yang menjadi kewenangannya kepada pemohon informasi publik, selain informasi yang dikecualikan berdasarkan ketentuan yang telah ditetapkan.

Undang-undang ini tidak hanya sekedar mengatur hak atas informasi, melainkan juga mengatur tentang hak akses terhadap informasi tersebut, hal ini tercermin dari asas-asas yang terkandung dalam undang-undang ini, diantaranya bahwa setiap informasi publik bersifat terbuka dan dapat diakses dan diperoleh oleh publik dengan cepat, tepat waktu, biaya ringan, dan cara sederhana. ${ }^{4}$

Berdasarkan ketentuan tersebut jelas bahwa setiap badan publik mempunyai kewajiban untuk memberikan informasi yang dibutuhkan masyarakat, termasuk Badan Pemeriksa Keuangan (BPK) sebagai salah satu badan publik yang bertugas melakukan pemeriksaan atas pengelolaan dan tanggung jawab keuangan negara. Sebagai lembaga tinggi negara dalam sistem ketatanegaraan Indonesia, yang berkedudukan di Ibukota negara dan memiliki perwakilan di setiap provinsi, pemeriksaan BPK atas pengelolaan dan tanggung jawab keuangan negara mencakup pemeriksaan keuangan, pemeriksaan kinerja, dan pemeriksaan dengan tujuan tertentu berdasarkan standar pemeriksaan keuangan negara yang hasil pemeriksaannya diserahkan kepada DPR, DPD, dan DPRD sesuai dengan kewenangannya untuk ditindaklanjuti.

Transparansi BPK untuk membuka laporan hasil pemeriksaan (LHP) sebagaimana amanat UUD 1945 ditegaskan dalam Pasal 19 ayat (1) UU Nomor 15 Tahun 2004 tentang Pemeriksaan Pengelolaan dan Tanggung Jawab Keuangan Negara dan Pasal 7 ayat (5) UU Nomor 15 Tahun 2006 tentang BPK, yang menyatakan bahwa LHP atas pengelolaan dan tanggung jawab keuangan negara yang telah diserahkan kepada lembaga perwakilan (DPR, DPD, dan DPRD) dinyatakan terbuka untuk umum.

Mekanisme untuk mendapatkan layanan informasi, setiap badan haruslah tetap memprioritaskan kualitas informasi dan pelayanan. Karena itu secara teknik, kualitas pelayanan juga mengedepankan prinsip cepat, tepat waktu, sederhana, dan biaya ringan. Untuk mewujudkan layanan yang berkualitas, ketentuan dalam Pasal 13 UU KIP mengisyaratkan bahwa setiap badan publik menunjuk Pejabat Pengelola Informasi dan Dokumentasi (PPID) dengan tugas mengembangkan sistem penyediaan pelayanan yang terstandardisasikan secara nasional. ${ }^{5}$

Sebagai implementasi amanat UUD 1945 tentang transparansi pengelolaan keuangan negara dan UU KIP, BPK telah menindaklanjuti hal tersebut dengan menetapkan Peraturan BPK Nomor 3 Tahun 2011 tentang Pengelolaan Informasi Publik pada BPK dan menunjuk Pejabat Pengelola Informasi dan Dokumentasi (PPID) melalui Keputusan Sekretaris Jenderal BPK RI Nomor 272/K/X-XIII.2/6/2015 tentang PPID di Lingkungan BPK. PPID merupakan pejabat yang bertanggung jawab di bidang penyimpanan, pendokumentasian, penyediaan, dan/atau pelayanan informasi di badan publik, yang berkedudukan di Pusat dan BPK Perwakilan, termasuk pada BPK Perwakilan Provinsi Jambi.

Badan ini telah berupaya mengimplementasikan kewajiban untuk memenuhi hak publik untuk mendapatkan informasi yang berada di bawah pengelolaannya berdasarkan prinsip-prinsip pemberian layanan sebagaimana diatur dalam UU KIP, namun dalam pelaksanaannya ditemukan adanya permasalahan sehingga perlu dilakukan upaya untuk mengatasinya. Karena itu penulis merasa tertarik untuk membahas lebih lanjut tentang implementasi pemberian informasi publik pada BPK Perwakilan Propinsi Jambi tersebut.

\section{Rumusan Masalah}

Berdasarkan uraian di atas, maka permasalahan dalam tulisan ini sebagai berikut:

1. Apakah implementasi pemberian informasi publik pada BPK Perwakilan Jambi telah mencerminkan asas-asas pemberian informasi publik berdasarkan Undang-Undang Nomor 14 Tahun 2008 tentang Keterbukaan Informasi Publik?

\footnotetext{
${ }^{3}$ Nunuk Febriananingsih, Keterbukaan Informasi Publik DalamPemerintahan Terbuka Menuju Tata Pemerintahan Yang baik, Jurnal Rechtsvinding, Volume1 Nomor 1, April 2012

${ }^{4}$ Henri Subagiyo dkk, Anotasi Undang-Undang Nomor 14 Tahun 2008 Tentang Keterbukaan Informasi Publik, Komisi Informasi Pusat, Jakarta, 2009, hal. 13

${ }^{5}$ Deddy Mulyadi, Studi Kebijakan Publik dan Pelayanan Publik "Konsep dan Aplikasi Proses Kebijakan Publik Berbasis Analisis Bukti untuk Pelayanan Publik”, Alfabeta, Bandung, 2015, hlm 237.
} 
Herma Yanti, Implementasi Pemberian Informasi Publik Pada Badan Pemeriksa Keuangan Perwakilan Provinsi Jambi Berdasarkan Undang-Undang Nomor 14 Tahun 2008 Tentang Keterbukaan Informasi Publik

2. Apa saja masalah-masalah yang dihadapi BPK Perwakilan Provinsi Jambi dalam pemberian informasi publik serta upaya untuk mengatasi permasalahan tersebut?

\section{Landasan Teori}

Undang-Undang Nomor 14 Tahun 2008 tentang Keterbukaan Informasi Publik telah mengamanahkan secara tegas dalam Pasal 7 ayat (1) tentang kewajiban bagi setiap badan publik untuk menyediakan, memberikan atau menerbitkan informasi publik yang berada di bawah kewenangannya kepada pemohon informasi publik, selain informasi yang dikecualikan berdasarakan ketentuan yang telah ditetapkan. Ketentuan tersebut sejalan dengan hak setiap orang untuk mendapatkan informasi yang diperlukan bagi pengembangan diri maupun lingkungan sosialnya sebagai salah satu hak asasi manusia yang dijamin pemenuhannya dalam konstitusi.

Ketentuan undang-undang tersebut juga menegaskan bahwa pemberian informasi public dilaksanakan berlandaskan pada beberapa asas-asas, diantaranya pertama, setiap informasi publik bersifat terbuka dan dapat diakses oleh setiap pengguna informasi publik; kedua, informasi publik yang dikecualikan bersifat ketat dan terbatas; ketiga, setiap informasi publik harus dapat diperoleh dengan cepat dan tepat waktu, biaya ringan, dan cara sederhana; dan keempat,informasi publik yang dikecualikan bersifat rahasia sesuai dengan undang-undang, kepatutan, dan kepentingan umum didasarkan pada pengujian tentang konsekuensi yang timbul apabila suatu informasi diberikan kepada masyakarat serta setelah dipertimbangkan dengan saksama bahwa menutup informasi publik dapat melindungi kepentingan yang lebih besar daripada membukanya atau sebaliknya.

\section{METODE PENELITIAN}

Penelitian ini merupakan penelitian hukum empiris dengan pendekatan socio legal research, dalam hal ini menelaah ketentuan peraturan perundang-undangan terkait dengan asas-asas dalam pemberian informasi publik berdasarkan UU KIP dan melihat implementasinya dalam pemberian informasi publik pada BPK Perwakilan Provinsi Jambi. Adapun populasi dalam penelitian ini adalah pegawai BPK Perwakilan Propinsi Jambi dan masyarakat yang memanfaatkan informasi publik pada BPK Perwakilan Propinsi Jambi. Terhadap pegawai tersebut dilakukan penarikan sampel secara purposive sampling sebanyak 3 (tiga) orang dan terhadap masyarakatan diambil sampel secara accidental sampling sebanyak 2 (dua) orang.

Pengumpulan data penelitian dilakukan melalui studi dokumen, yaitu dengan mempelajari dokumen-dokumen yang berkaitan dengan masalah yang diteliti dan yang tersedia pada BPK Perwakilan Propinsi Jambi, dan melalui wawancara dengan responden yang telah ditetapkan. Selanjutnya data-data tersebut kemudian diolah dan dianalisis secara kualitatif menggunakan konsep yang telah ditetapkan yang bermuara pada kesimpulan sesuai permasalahan yang dikemukakan.

\section{HASIL DAN PEMBAHASAN}

\section{Implementasi Pemberian Informasi Publik pada BPK Perwakilan Provinsi Jambi}

Sebagaimana dijelaskan sebelumnya bahwa untuk pengelolaan informasi public pada BPK Perwakilan Provinsi Jambi telah dibentuk Pejabat Pengelola Informasi dan Dokumentasi (PPID) yang bertanggungjawab di bidang penyimpanan, pendokumentasian, penyediaan, dan/atau pelayanan informasi di badan publik. PPID di BPK Perwakilan Provinsi Jambi merupakan seluruh pejabat struktural yang susunannya terdiri dari Kepala Perwakilan menjabat selaku PPID, Kepala Sekretariat Perwakilan selaku Sekretaris/Ketua PIK, dan Kepala Subauditorat beserta Seluruh Kepala Subbagian yang bertanggung jawab di masing-masing bidangnya selaku Pejabat Pembantu PPID. Pelaksanaan tugas teknis PPID BPK dilakukan oleh PIK sebagai unit pelaksana pengelolaan dan pelayanan informasi publik. Pelaksanaan tugas PIK berada di bawah kewenangan Subbagian Humas dan Tata Usaha Kepala Perwakilan.

Terkait dengan informasi publik di BPK Perwakilan Provinsi Jambi tidak hanya berupa LHP, namun juga meliputi informasi lain seperti profil lembaga, struktur organisasi, rencana strategis, dan informasi kepegawaian. Akan tetapi tidak semua informasi publik bersifat terbuka dan wajib diberikan oleh BPK Perwakilan Provinsi Jambi kepada publik/masyarakat. Informasi tidak dapat diberikan apabila termasuk dalam kategori informasi publik yang dikecualikan dan BPK Perwakilan Provinsi Jambi berhak menolak memberikan informasi yang dikecualikan tersebut sesuai dengan ketentuan perundang-undangan. Bagi pemohon informasi yang tidak puas atas informasi yang tidak dapat diterima maupun atas pelayanan yang tidak sesuai standar, BPK menyediakan wadah untuk mengajukan keberatan.

Adapun informasi publik tersebut terdiri dari beberapa kategori yang meliputi:

1. Informasi yang wajib disediakan dan diumumkan secara berkala meliputi:

a. Informasi yang berkaitan dengan BPK:

1) Alamat kantor BPK;

2) Profil BPK; 
3) Rencana strategis;

4) Tugas dan wewenang;

5) Bidang tugas pimpinan;

6) Struktur organisasi;

7) Laporan Harta Kekayaan Pejabat Negara;

8) LHP; dan

9) Ikhtisar Hasil Pemeriksaan Semester (IHPS).

b. Informasi mengenai kegiatan dan kinerja BPK:

1) Agenda BPK;

2) Layanan publik BPK;

3) Penerimaan CPNS BPK; dan

4) Laporan Akuntabilitas Kinerja BPK.

c. Informasi mengenai Laporan Keuangan BPK:

1) Laporan Keuangan BPK Audited; dan

2) Rencana Kerja dan Anggaran BPK.

d. Informasi lainnya:

1) Ringkasan Pelayanan Informasi Publik;

2) Prosedur permintaan informasi;

3) Prosedur pengaduan masyarakat;

4) Pengadaan barang dan jasa; dan

5) Jaringan Dokumentasi dan Informasi Hukum BPK.

2. Informasi yang wajib diumumkan secara serta merta:

BPK belum memiliki informasi yang wajib disediakan dan diumumkan secara serta-merta.

3. Informasi yang wajib disediakan setiap saat meliputi:

a. Daftar seluruh informasi publik yang berada di bawah penguasannya, tidak termasuk informasi yang dikecualikan;

b. Peraturan, Keputusan dan/atau Kebijakan BPK;

c. Informasi terkait Organisasi, Administrasi, Kepegawaian, dan Keuangan BPK;

d. Informasi Mengenai Pedoman Pelayanan BPK; dan

e. Laporan Pelayanan PIK.

4. Informasi yang dikecualikan:

Daftar Informasi Publik yang dikecualikan di Lingkungan BPK ditetapkan dengan Peraturan Sekretaris Jenderal BPK Nomor 1 Tahun 2018 tentang Daftar Informasi Publik yang Dikecualikan di Lingkungan Badan Pemeriksa Keuangan.

Dalam pemberian informasi berdasarkan wawancara dengan Eko Gemini Putra Fisabilillah selaku staf Humas dan TU Kepala BPK Perwakilan Provinsi Jambi, mengungkapkan bahwa:

"Pemberian informasi publik di BPK Perwakilan Provinsi Jambi mengacu pada Peraturan BPK Nomor 3 Tahun 2011 tentang Pengelolaan Informasi Publik pada BPK serta teknis kegiatannya dilaksanakan oleh Tim Pusat Informasi dan Komunikasi yang ditetapkan berdasarkan Keputusan Kepala Perwakilan BPK Provinsi Jambi Nomor 16/K/XVIII.JMB/2/2019 tanggal 1 Februari 2019 tentang Tim PIK pada BPK Perwakilan Provinsi Jambi TA 2019 yang menjabarkan struktur organisasi Pusat Informasi dan Komunikasi, uraian tugas, dan tanggung jawab PIK. Mekanisme pemberian informasi publik berpedoman kepada Prosedur Operasional Standar (POS) Pelayanan dan Pengelolaan Informasi Publik". ${ }^{6}$

Berdasarkan penjelasan tersebut terlihat bahwa BPK Perwakilan Provinsi Jambi telah memiliki kebijakan terkait pelayanan dan pengelolaan informasi dan panduan prosedur pelaksanaannya dalam bentuk POS yang telah ditetapkan oleh BPK.

Adapun mekanisme pemberian informasi publik pada BPK Perwakilan Provinsi Jambi adalah sebagai berikut:

1. Permintaan informasi diajukan oleh pemohon informasi melalui surat yang ditujukan kepada Kepala Perwakilan selaku PPID melalui PIK baik dengan datang langsung ke PIK BPK Perwakilan Provinsi Jambi atau melaluiemail/fax/pos. 
2. Untuk mendapatkan informasi publik, perlu dilakukan pengisian formulir permintaan informasi. Ketentuan pengisian formulir permintaan informasi adalah sebagai berikut:

a. Bagi pemohon informasi publik yang datang langsung, dapat mengisi formulir permintaan informasi dengan melampirkan fotokopi identitas diri dan/atau surat permintaan.

b. Bagi pemohon informasi publik yang melalui e-mail/fax/pos, permintaan informasi dilampiri dengan scan identitas diri dan pengisian formulir dilakukan oleh Petugas PIK dengan mengikuti penomoran pelayanan permintaan informasi di PIK.

3. Petugas PIK meneruskan permintaan informasi tersebut kepada PPID.

4. PPID mendisposisikan surat permintaan informasi dari pemohon kepada Sekretaris PPID, apabila diperlukan dapat melibatkan Pejabat Pertimbangan Pelayanan Informasi Publik untuk memberikan masukan/saran. Sekretaris PPID menerima dan mendisposisikan kepada Petugas PIK.

5. Petugas PIK mencatat data permintaan informasi untuk di-input ke dalam database register permintaan informasi dan mengarsipkan dokumen formulir permintaan informasi tersebut.

6. Petugas PIK melakukan verifikasi atas permintaan informasi, dengan melihat kriteria-kriteria sebagai berikut:

a. Terkait kelengkapan;

b. Kesesuaian; dan

c. Jenis informasi.

7. Jika permintaan informasi tersebut tidak lolos verifikasi, maka Petugas PIK menyampaikan tanggapan kepada pemohon informasi paling lama 10 (sepuluh) hari kerja sejak permintaan informasi diterima oleh Petugas PIK.

8. Jika permintaan informasi tersebut lolos verifikasi dan informasi tersebut tersedia di database PIK, maka Petugas PIK memberikan dokumen informasi publik tersebut secara langsung kepada pemohon informasi dalam bentuk softcopy atau hardcopy. Penyerahan dokumen informasi disertai dengan surat jawaban dan formulir tanda terima permintaan informasi, dengan jangka waktu paling lama 10 (sepuluh) hari kerja sejak permohonan informasi diterima oleh petugas PIK.

9. Apabila informasi yang diminta termasuk dalam kategori informasi yang dikecualikan maka PPID menyampaikansurat jawaban yang memuat alasan penolakan sesuai dengan ketentuan peraturan perundangundangan yang berlaku.

10.PIK dapat memperpanjang waktu untuk mengirimkan jawaban permohonan informasi paling lambat 7 (tujuh) hari kerja berikutnya dengan memberikan alasan secara tertulis.

11.Petugas PIK menyusun dan menyampaikan konsep laporan layanan permintaan informasi bulanan/tahunan kepada Sekretaris PPID, paling lambat 10 (sepuluh) hari setelah bulan berakhir.

Berdasarkan mekanisme di atas tergambar bahwa permohonan permintaan informasi dapat dilakukan secara langsung, tetapi juga dapat dikirimkan melalui email/fax maupun pos.Mekanisme tersebut menggambarkan adanya kemudahan bagi masyarakat untuk mendapatkan informasi. Begitu juga dari segi waktu, pemohon informasi tidak perlu menunggu terlalu lama karena telah ditentukan batas waktu pemberian jawaban atas permohonan tersebut ditentukan paling lama selama 10 (sepuluh) hari. Dari mekanisme tersebut tercermin adanya asas bahwa setiap informasi public harus dapat diperoleh dengan cepat dan tepat waktu, biaya ringan dan cara sederhana.

Penyediaan dan pemberian informasi publik pada BPK Perwakilan Provinsi Jambi menggunakan saluran informasi melalui website dan Pusat Informasi dan Komunikasi (PIK) sebagai sarana pengelolaan dan pelayanan informasi publik sebagaimana diamanatkan oleh UU KIP. Hal ini disampaikan oleh Sandra Fitriasari, salah seorang petugas PIK BPK Perwakilan Jambi yang mengungkapkan bahwa:

"BPK Perwakilan Provinsi Jambi telah menyediakan pelayanan online melalui e-PPID yang termuat dalam laman website yang memudahkan pemohon informasi memperoleh informasi publik yang dikehendaki dengan mudah dan bebas biaya. Pada e-PPID memuat semua informasi terkait pelayanan informasi publik antara lain daftar informasi publik yang berada di bawah kewenangan BPK Perwakilan Provinsi Jambi, daftar informasi publik yang dikecualikan, persyaratan dan prosedur permintaan informasi, serta jenis-jenis informasi yang wajib diumumkan dan disediakan secara berkala dapat dengan mudah diakses oleh masyarakat". ${ }^{7}$

Berdasarkan hasil wawancara tersebut jelas bahwa penyediaan informasi publik melalui website menunjukkan adanya asas keterbukaan informasi pada BPK Perwakilan Provinsi Jambi. Setiap informasi publik bersifat terbuka dan dapat diakses oleh setiap pengguna informasi, sehingga informasi dapat diperoleh cepat, biaya ringan dan cara sederhana. Melalui penerapan asas tersebut, masyarakat dapat mengetahui informasi publik dengan cara akses 
langsung secara elektronik melalui situs website BPK Perwakilan Provinsi Jambi tanpa perlu melakukan registrasi pelayanan ataupun dengan mengajukan permohonan secara tertulis kepada Kepala Perwakilan dan melakukan registrasi pelayanan.

Lebih lanjut Sandra Fitriasari mengemukakan bahwa:

" informasi yang dapat diakses langsung oleh pemohon informasi melalui website adalah kategori Informasi yang wajib disediakan dan diumumkan secara berkala dan sebagian informasi yang wajib disediakan setiap saat yang tidak perlu melakukan registrasi pelayanan. Khusus untuk LHP yang merupakan informasi yang wajib disediakan dan diumumkan secara berkala, informasi berupa daftar LHP dapat diakses melalui website, sedangkan untuk permohonan LHP dapat diakses melalui mekanisme pengajuan secara tertulis kepada Kepala Perwakilan dan registrasi pelayanan". 8

Hal tersebut sesuai dengan Pasal 15 ayat (4) Peraturan BPK Nomor 3 Tahun 2011 tentang Pengelolaan Informasi Publik pada BPK yang menyatakan bahwa informasi yang dapat diakses oleh pemohon informasi publik setelah melakukan registrasi secara elektronik adalah informasi berupa LHP atas Laporan Keuangan, LHP Kinerja, dan LHP Dengan Tujuan Tertentu.

Terkait dengan saluran informasi melalui PIK, saluran ini berfungsi sebagai sarana penerimaan permintaan informasi, pengaduan masyarakat, maupun keberatan atas informasi yang disampaikan BPK. Pelaksanaan tugas PIK berada di bawah kewenangan Subbagian Humas dan Tata Usaha Kepala Perwakilan. Adapun rincian kegiatan dari PIK meliputi:

1. Pelayanan permintaan informasi publik:

Pemberian informasi yang termasuk ke dalam kategori informasi publik kepada publik/pemangku kepentingan oleh BPK yang berkenaan dengan hasil pemeriksaan maupun non pemeriksaan.

2. Pelayanan keberatan atas informasi BPK:

Penerimaan dan pemprosesan dari adanya keluhan atas informasi yang disampaikan oleh BPK, baik dalam hal pemeriksaan maupun nonpemeriksaan, yang disampaikan oleh publik.

Untuk melaksanakan tugas PIK ini, BPK Perwakilan Provinsi Jambi telah menyediakan ruangan khusus untuk pelayanan informasi publik di lantai 1 kantor BPK Perwakilan Provinsi Jambi dengan nama PIK BPK Perwakilan Provinsi Jambi, yang telah dilengkapi dengan berbagai fasilitas pendukung yang nyaman dan sumber daya dalam pemberian pelayanan informasi sebanyak 6 (enam) orang petugas PIK dengan pembagian tugas yang telah ditentukan masing-masingnya.

Selain kedua saluran tersebut, untuk mendukung proses pengelolaan informasi publik, BPK telah memiliki berbagai formulir yang digunakan dalam kegiatan pelayanan permintaan informasi publik yaitu: formulir permintaan informasi public, formulir tanda terima penyerahan dokumen informasi publik; dan formulir keberatan atas informasi.

Melalui sarana, sumberdaya serta saluran-saluran yang tersedia tersebut, juga mencerminkan upaya BPK Perwakilan Jambi untuk mewujudkan keterbukaan informasi publik serta memberikan kemudahan bagi masyarakat dalam mememperoleh informasi yang dibutuhkan dengan cepat, mudah dan biaya ringan, sesuai dengan asas-asas dalam pelayanan informasi publik.

Untuk mengetahui implementasi pemberian informasi publik pada BPK Perwakilan Provinsi Jambi ini dapat dilihat dari jumlah permintaan informasi yang diajukan pemohon informasi selama Tahun 2019 berdasarkan kategori informasi informasi serta ada tidaknya keberatan atas permintaan informasi tersebut dapat dilihat pada tabel berikut :

Tabel 1. Jenis Permintaan Informasi

\begin{tabular}{clcc}
\hline No. & \multicolumn{1}{c}{ Jenis Informasi } & Jumlah & Keberatan atas Informasi \\
\hline 1. & Berkala & 27 & - \\
2. & Serta Merta & - & - \\
3. & Setiap Saat & - & - \\
4. & Dikecualikan & 4 & - \\
& JUMLAH & 31 & - \\
\hline
\end{tabular}

Sumber: PIK BPK Perwakilan Provinsi Jambi

Dari Tabel di atas dapat diketahui bahwa salama Tahun 2019, BPK Perwakilan Provinsi Jambi telah melayani 31 permintaan informasi yang terdiri dari 27 informasi berkala dan 4 informasi yang dikecualikan. Dari jumlah tersebut tidak terdapat adanya keberatan yang diajukan pemohon informasi. 
Berdasarkan informasi yang diperoleh dari responden, permintaan informasi berkala yang diterima BPK Perwakilan Provinsi Jambi seluruhnya merupakan informasi mengenai LHP. Sebagian besar tujuan permintaan atas informasi tersebut adalah sebagai data penelitian (tugas akhir, skripsi, atau tesis), kontrol sosial, pengawasan, penyelidikan, dan penyelesaian tindak lanjut hasil pemeriksaan BPK. Sebagimana diketahui bahwa hasil setiap pemeriksaan atas pengelolaan dan tanggung jawab keuangan negara yang dilakukan oleh BPK disusun dan disajikan dalam LHP setelah kegiatan pemeriksaan berakhir. LHP yang telah diserahkan kepada DPR, DPD, dan DPRD dinyatakan terbuka untuk umum, kecuali yang memuat rahasia negara dan/atau mengandung unsur pidana yang diproses hukum sebagaimana diatur dalam ketentuan peraturan perundang-undangan. LHP BPK yang disampaikan kepada publik tersebut meliputi LHP Keuangan, LHP Kinerja; dan LHP Dengan Tujuan Tertentu kecuali LHP Investigatif.

LHP Investigatif termasuk salah satu kategori informasi publik yang dikecualikan. Informasi publik yang dikecualikan adalah informasi publik yang tidak dapat diakses oleh publik. Informasi tersebut bersifat rahasia sesuai dengan undang-undang, kepatutan, dan kepentingan umum sebagaimana tercermin dalam salah satu asas pemberian informasi publik sebagaimana diatur dalam Pasal 2 ayat (4) UU KIP. Terhadap informasi yang dikecualikan tersebut, Eko Gemini Putra Fisabillah, staf Subbagian Humas dan TU pada BPK Perwakilan Provinsi Jambi mengungkapkan bahwa:

"Informasi publik yang dikecualikan tersebut bukanlah sesuatu yang statis melainkan dinamis, selalu berubah sejalan dengan dinamika mayarakat, situasi dan kondisi, serta waktu. Untuk itu, PPID BPK selalu melakukan pengujian tentang konsekuensi sebelum menyatakan suatu informasi publik dikecualikan sebagai informasi publik yang dapat diakses. Proses uji konsekuensi atas permintaan informasi yang dikecualikan atau permintaan informasi yang ditolak untuk diberikan berdasarkan pada ketentuan peraturan perundang-undangan: ${ }^{9}$

Uraian dan pernyataan di atas menggambarkan bahwa pemberian informasi publik pada BPK Perwakilan Provinsi Jambi juga dikecualikan terhadap informasi tertentu yang bersifat rahasia sehingga tidak dapat diakses oleh masyarakat. Dalam hal ini, BPK Perwakilan Provinsi Jambi berhak menolak memberikan informasi yang dikecualikan tersebut setelah melakukan pengujian konsekuensi sesuai dengan kentuan perundang-undangan. Namun pengecualian tersebut juga tidak bersifat mutlak, tergantung pada hasil pengujian yang dilakukan PPID sebagai pejabat yang bertanggung jawab dalam pelayanan informasi. Pernyataan tersebut sekaligusd mencerminkan telah diterapkannya asas bahwa informasi public yang dikecualikan bersifat ketat dan terbatas sebagaimana diatur dalam UU KIP.

Guna mengetahui implementasi dari mekanisme permintaan data secara tertulis pada BPK Perwakilan Jambi, Agustin Sahara sebagai salah seorang responden masyarakat yang menggunakan informasi public berupa LHP, mengungkapkan bahwa:

"Kami mengajukan permohonan informasi tertulis berupa LHP atas LKPD Kota Jambi Tahun 2016-2018 dan ditemui oleh petugas PIK. Kemudian mengisi formulir permintaan informasi publik yang dilampirkan fotokopi KTP. Kemudian data diproses lebih lanjut oleh Petugas PIK. Setelah 3 (tiga) hari kemudian dihubungi bahwa data telah di-email lengkap beserta dengan formulir tanda terima penyerahan dokumen informasi publik". ${ }^{10}$

Berdasarkan penjelasan responden juga terlihat bahwa pemberian pelayanan informasi dilakukan oleh petugas mulai dari memproses permohonan hingga pemberian informasi dengan tidak melebihi jangka waktu yang ditentukan yaitu 10 (sepuluh) hari kerja. Informasi disampaikan kepada pemohon hanya dalam waktu 3 (tiga) hari dari pengajuan permohonan dan diberikan dalam bentuk softcopy sehingga tidak memerlukan biaya. Selain itu, dalam surat jawaban kepada pemohon informasi juga mencantumkan informasi sebagaimana ditentukan dalam UU KIP. Hal ini menunjukkan bahwa pemberian informasi publik di BPK Perwakilan Provinsi Jambi dapat dikatakan sesuai dengan ketentuan yang tercantum dalam POS yang telah ditetapkan, sekaligus mencerminkan telah diimpelemntasikannya asas keterbukaan informasi serta pemberian informasi publik dengan cepat, tepat waktu, biaya ringan dan cara yang sederhana sebagaimana diamanahkan dalam UU KIP.

${ }^{9}$ Eko Gemini Putra Fisabilillah, Staf Subbagian Humas dan TU Kepala Perwakilan BPK Perwakilan Provinsi Jambi, Wawancara Penulis 29 November 2019.

${ }^{10}$ Agustin Sahara, masyarakat, Wawancara Penulis 29 November 2019 


\section{Masalah-Masalah yang Dihadapi BPK Perwakilan Provinsi Jambi dalam Pemberian Informasi Publik dan Upaya untuk Mengatasinya}

Meskipun implementasi pemberian informasi publik pada BPK Perwakilan Provinsi Jambi telah dilaksanakan mengikuti ketentuan dan mekanisme yang ditetapkan, namun dalam pemberian informasi public tersebut juga ditemui adanya beberapa permasalahan.

Berdasarkan wawancara terkait pelayanan pemberian informasi publik dengan Nur Hasniwati sebagai mahasiswa yang memanfaatkan hasil pemeriksaan sebagai bahan penelitian mengungkapkan bahwa " "pelayanan PIK BPK Perwakilan Provinsi Jambi sudah memuaskan, mungkin BPK bisa menyediakan informasi LHP yang lebih lengkap di website untuk memudahkan para pengguna untuk mendapat informasi yang lebih banyak terkait hasil pemeriksaan".

Mengenai permasalahan LHP tersebut, dijelaskan oleh Mekrolius salah seorang Petugas PIK bahwa:

"Permohonan LHP diajukan dengan melakukan registrasi pelayanan dan permohonan secara tertulis kepada Kepala Perwakilan sesuai dengan Peraturan BPK Nomor 3 Tahun 2011 tentang Pengelolaan Informasi Publik pada BPK. Tujuannya adalah sebagai kontrol pemanfaatan hasil pemeriksaan oleh masyarakat. BPK Perwakilan Provinsi Jambi telah memuat informasi seluruh daftar LHP yang diterbitkan untuk mempermudah masyarakat dalam mengetahui dan mengajukan permohonan hasil pemeriksaan yang telah dilakukan oleh BPK Perwakilan Provinsi Jambi”. ${ }^{11}$

Lebih lanjut dijelaskan bahwa LHP sebagai hasil kerja BPK sebagai lembaga eksternal pemeriksa keuangan negara merupakan salah bentuk akuntabilitas BPK kepada para pemangku kepentingan dan publik. Melalui LHP juga ditegakkan transparansi dan akuntabilitas keuangan negara. Tingginya tingkat kebutuhan masyarakat terhadap transparansi dan akuntabilitas pengelolaan dan tanggung jawab keuangan negara menuntut LHP dimuat secara terbuka di website. Dibutuhkan kebijakan yang sesuai antara BPK dan Pemerintah mengenai prosedur pemberian LHP kepada publik dengan diakses secara langsung melalui website atau melalui rangkaian prosedur permintaan yang ditetapkan. Hal ini penting agar terdapat persamaan pendapat antara internal dan eksternal BPK, sehingga tidak ada lagi masyarakat yang mempersoalkan LHP yang tidak dapat diakses secara langsung.

Selain itu, berdasarkan informasi yang disampaikan Agustin Sahara bahwa:” pemberian informasi sudah sesuai dan tepat waktu, namun sebagian informasi tidak dapat diterima karena termasuk informasi yang dikecualikan, dan belum mengetahui bahwa ada informasi yang dikecualikan".

Berdasarkan penjelasan tersebut tergambar bahwa belum semua masyarakat memahami kebijakan tentang keterbukaan informasi publik pada BPK. Keterbukaan informasi publik ini dibatasi oleh hal-hal tertentu sehingga tidak semua informasi bisa diberikan kepada masyarakat.

Selain itu, adanya permasalahan-permasalahan tersebut dipertegas oleh Mekrolius yang menjelaskan bahwa: "Selama Tahun 2019, BPK Perwakilan Provinsi Jambi menemukan kendala-kendala dalam pemberian informasi publik yaitu masih terdapat permohonan informasi yang salah alamat, tidak lengkap, dan tidak mencantumkan informasi publik yang diminta secara jelas sesuai prosedur yang ditetapkan serta tidak mengetahui informasi yang dikecualikan". ${ }^{12}$

Permasalahan tersebut disebabkan karena tingkat keingintahuan masyarakat terhadap BPK Perwakilan Provinsi Jambi yang terus meningkat. Namun, belum diimbangi dengan tingkat pemahaman masyarakat atas tugas dan fungsi BPK Perwakilan Provinsi Jambi sebagai badan publik yang melaksanakan pemeriksaan atas pengelolaan dan tanggung jawab keuangan daerah beserta kebijakan dan mekanisme pemberian informasi publik yang telah ditetapkan.

Untuk mengantisipasi hambatan yang ditemui oleh masyarakat atas permintaan informasi publik kepada BPK Perwakilan Provinsi Jambi dan untuk mengetahui tingkat kepuasaan masyarakat, maka pada saat pemberian informasi publik, PIK BPK Perwakilan Provinsi Jambi meminta kesediaan masyarakat untuk mengisi formulir survei atas mutu layanan dan kualitas Kerja Pelayanan Informasi Publik sebagai penyaluran aspirasi publik untuk mendapatkan pelayanan yang lebih baik. Survei tersebut berisi penilaian terhadap beberapa aspek layanan yaitu informasi yang tersedia, pelayanan petugas, sarana dan prasana, serta permintaan saran/masukan pada tempat yang telah disediakan. Hasil survey diumumkan secara terbuka melalui website dan PIK serta dilakukan tindak lanjut dan dievaluasi secara berjenjang. Pada Website BPK Perwakilan Provinsi Jambi juga disediakan kolom penilaian kepuasan masyarakat terhadap pelayanan publik kepada pengunjung website. Saat ini juga sudah disediakan layar informasi secara digital melalui layar sentuh yang ditempatkan di bagian lobi kantor BPK Perwakilan Provinsi Jambi untuk memudahkan masyarakat mendapatkan informasi secara langsung.

\footnotetext{
${ }^{11}$ Mekrolius, Petugas PIK BPK Perwakilan Provinsi Jambi, Wawancara Penulis 5 Desember 2019
}

${ }^{12}$ Mekrolius, Petugas PIK BPK Perwakilan Provinsi Jambi, Wawancara Penulis 5 Desember 2019 
Selain itu, untuk memperbaiki dan meningkatkan kualitas pelayanan pemberian informasi publik, telah disusun rencana tindak lanjut yang akan dilaksanakan di masa yang akan datang yaitu sebagaimana dikemukakan oleh Mekrolius, yaitu :

1. Melaksanakan rapat PPID dan PIK untuk membahas permasalahan-permasalahan terkait dengan informasi publik dan peningkatan pelayanan informasi publik;

2. Memaksimalkan fungsi PIK serta penggunaan website dan e-PPID dalam rangka penyerbaluasan informasi publik; dan

3. Melakukan peningkatan kompetensi petugas PIK secara berkelanjutan.

Berdasarkan penjelasan tersebut, tergambar upaya-upaya yang dilakukan BPK Perwakilan Provinsi Jambi untuk mengatasi hambatan yang timbul dalam pemberian informasi publik dalam rangka meningkatkan kualitas pelayanan yang lebih baik. Namun demikian, fungsi PIK BPK Perwakilan Provinsi Jambi dalam rangka meningkatkan keterbukaan informasi masih perlu dioptimalkan, selain pelayanan seluruh informasi yang berkaitan dengan keterbukaan informasi melalui PIK maupun website, perlu diimbangi dengan sosialisasi langsung kepada masyarakat terkait dengan berbagai kebijakan maupun jenis-jenis informasi yang dapat langsung diakses ataupun melalui prosedur permohonan, persyaratan permohonan informasi, dan mekanisme pemberian informasi publik secara rinci,sehingga penyebarluasan informasi publik kepada masyarakat dapat lebih optimal dalam rangka memenuhi hak dan kebutuhan dasar masyarakat untuk memperoleh informasi.

\section{SIMPULAN}

Berdasarkan uraian yang telah dikemukakan, dapat diambil kesimpulan sebagai berikut:

1. Implementasi pemberian informasi public pada BPK Perwakilan Provinsi Jambi dapat dikatakan telah mencerminkan asas-asas pemberian informasi publik sebagaimana ditentukan dalam UU KIP. Hal ini karena telah tersedianya informasi yang dapat diakses oleh masyarakat secara langsung melalui Pusat Informasi dan Komunikasi yang dilengkapi dengan berbagai fasilitas pendukung dan pelayanan online melalui website BPK sehingga masyarakat dapat memperoleh informasi yang diperlukan kecuali terhadap kategori informasi publik tertentu yang dikecualikan sesuai ketentuan undang-undang. Terhadap informasi yang dikecualikan juga dilakukan pengkajian sehingga dapat berubah sesuai dengan perkembangan situasi, kondisi dan waktu berdasarkan ketentuan yang berlaku. Dengan demikian implementasi pemberian informasi public tersebut telah berlandaskan atas keterbukaan informasi, pemberian pelayanan secara cepat, mudah dan biaya ringan serta pemberlakuan asas bahwa informasi publik yang dikecualikan bersifat ketat dan terbatas.

2. Masalah-masalah yang dihadapi dalam pemberian informasi publik tersebut antara lain:

a. Tuntutan masyarakat terhadap pemuatan LHP secara terbuka di website.

b. Terdapat pemohon informasi yang mengajukan permintaan informasi tidak sesuai dengan persyaratan dan prosedur serta tidak mengetahui ketentuan atas informasi yang dikecualikan.

Upaya mengatasi permasalahan tersebut dilakukan dengan memberikan penjelasan dan pemahaman melalui Petugas Pusat Informasi dan Komunikasi, serta upaya peningkatan kualitas pelayanan dengan penyediaan formulir untuk menampung berbagai masukan dan keluhan-keluhan masyarakat atas pelayanan yang diberikan, dan menindaklanjutinya dengan menyusun beberapa perencanaan diantaranya memaksimalkan fungsi PIK, penggunaan website guna menyebarluaskan informasi dan peningkatan kompetensi petugas PIK secara berkelanjutan.

\section{DAFTAR PUSTAKA}

\section{Buku}

Badan Pemeriksa Keuangan Republik Indonesia, Mengenal Lebih Dekat BPK Sebuah Panduan Populer, Biro Humas danLuar Negeri BPK, Jakarta, 2011

Deddy Mulyadi, Studi Kebijakan Publik dan Pelayanan Publik "Konsep dan Aplikasi Proses Kebijakan Publik Berbasis Analisis Bukti untuk Pelayanan Publik", Alfabeta, Bandung, 2015

Henri Subagiyo dkk, Anotasi Undang-Undang Nomor 14 Tahun 2008 Tentang Keterbukaan Informasi Publik, Komisi Informasi Pusat, Jakarta, 2009.Suratman dan Philips Dillah, Metode Penelitian Hukum, Alfabeta, Bandung, 2015

\section{Peraturan Perundang-undangan}

Undang-Undang Dasar Negara Republik Indonesia Tahun 1945

Undang-Undang Nomor 15 Tahun 2004 tentang Pemeriksaan Pengelolaan dan Tanggung Jawab Keuangan Negara.

Undang-Undang Nomor 15 Tahun 2006 tentang Badan Pemeriksa Keuangan

Undang-Undang Nomor 14 Tahun 2008 tentang Keterbukaan Informasi Publik

Peraturan Badan Pemeriksa Keuangan Nomor 3 Tahun 2011 tentang Pengelolaan Informasi Publik 
Herma Yanti, Implementasi Pemberian Informasi Publik Pada Badan Pemeriksa Keuangan Perwakilan Provinsi Jambi Berdasarkan Undang-Undang Nomor 14 Tahun 2008 Tentang Keterbukaan Informasi Publik

\section{Jurnal}

Nunuk Febriananingsih, Keterbukaan Informasi Publik DalamPemerintahan Terbuka Menuju Tata Pemerintahan Yang baik, Jurnal Rechtsvinding, Volume1 Nomor 1, April 2012

\section{Internet}

Zahari, Implementasi Keterbukaan Informasi Melalui Optimalisasi Meja Informasi di Pengadilan Agama, diakses dari http://www.academia.edu/9253471. Diakses Tangal 31Desember 2019 